\title{
TEACHERS' EXPERIENCES IN INCORPORATING STUDENTS' FUNDS OF KNOWLEDGE TO PROMOTE THE LEARNING OF SCIENCE
}

\author{
Rohandi \\ Fakultas Keguruan dan Ilmu Pendidikan Universitas Sanata Dharma \\ email: rohandi@usd.ac.id
}

\begin{abstract}
Abstrak: Salah satu bidang kajian menarik bagi pendidik bidang sains di negara berkembang dan dalam budaya timur (non-Western) adalah hakikat interaksi antara praktik tradisi dan keyakinan yang ada di masyarakat tempat siswa tinggal dan sains yang diajarkan di sekolah. Penelitian ini bertujuan untuk mempertimbangkan isu-isu budaya dalam konteks pembelajaran sains di Indonesia. Keterkaitan antara budaya siswa, pengalaman siswa di rumah, dan pengalaman pengetahuan siswa yang diidentifikasi sebagai funds of knowledge, telah diintegrasikan ke dalam pembelajaran sains. Penelitian ini berlangsung di dua SMP di Indonesia. Dua guru dan 173 siswa (94 laki-laki dan 79 perempuan) berpartisipasi dalam penelitian ini. Hasil penelitian ini menunjukan bahwa kecocokan antara pengalaman hidup siswa, tingkat pengetahuan, dan konsep ilmu pengetahuan dapat menjadi faktor utama dalam menjaga keberlanjutan pembelajaran ilmiah pada kelas sains. Hal ini penting untuk mengembangkan pengajaran dan pembelajaran sains yang menekankan pada penggabungan pengetahuan siswa, terutama dalam menyajikan ilmu yang relevan dengan siswa kehidupan sehari-hari.
\end{abstract}

Kata Kunci: funds of knowledge, sekolah menengah, pembelajaran sains

\section{PENGALAMAN GURU DALAM MENGINTEGRASIKAN PENGALAMAN BUDAYA SISWA UNTUK MENINGKATKAN BELAJAR SAIN}

\begin{abstract}
One area of interest for science educators in developing countries and in non-Western settings is the nature of interaction between traditional practices and beliefs existing in the communities in which students live and the science taught in schools. The purpose of this study is to consider cultural issues in the context of the teaching of science in Indonesia. The connection between students' culture, home experiences and experiential knowledge of students which is identified as funds of knowledge have been incorporated into learning science. This study took place within two sub-urban Junior High Schools in Indonesia. Two teachers and 173 students (94 males and 79 females) participated in this study. This study findings reveals that "compatibility" between students' real-life experiences, their funds of knowledge, and science concepts can be the major factor in sustaining science learning in science classes. It is important worthwhile to develop the teaching and learning of science which put emphasis on incorporating students' funds of knowledge especially in presenting science that is relevant to students' everyday life.
\end{abstract}

Keywords: funds of knowledge, secondary school, teaching science

\section{INTRODUCTION}

Science educators in developing countries and in non-Western settings have been interested in the nature of the interaction between the traditional practices and beliefs existing in the communities in which students live and the science taught in school. George (1999) has identified from some research findings that the links between science as taught in schools and Western culture; and consequences for science education programs in different cultural settings need to be recognized and explored. Science education in Indonesia is expected to serve students in understanding themselves and the environment, and the application of science in everyday life. Science education in Indonesia put emphasis on the inquiry activities that guide students to obtain deep understanding of their environment (Depdiknas, 2006). New school curriculum promotes minimizing the number of 
facts taught in the curriculum in favour of treating fewer concepts but with greater depth. In inquiry-based teaching, students participate in investigations that require them to develop questions and hypotheses, collect data, analyze data, and draw and test conclusions. In science, as with any other subjects, the quality of learning depends largely on the quality of teaching.

It is also recognized that there are many cultural and economic differences within Indonesia. Indonesia is an archipelago with 17,000 islands inhabited by more than 350 ethnic groups speaking about 300 local languages and embracing various religions and beliefs in God Almighty (Semiawan \& Natawidjaja, 2000). Bahasa Indonesia has been recognized as the official national language. However, Semiawan and Natawidjaja (2000) indicate that the local languages still exist and Indonesia can be considered as a pluralistic society because of the diversity of languages, lifestyles, attitudes, and customs that are rooted in several ancient subcultures. This diversity should be considered in implementing curriculum (Semiawan \& Natawidjaja, 2000).

Researchers have found that a lack of connection especially characterizes students' experiences with school science, which has been documented to exclude the lives of marginalized groups (Lee \& Fradd, 1998). The students imagined the field of science as distant and inaccessible. Students might think of Einstein, lab coats, and goggles when asked about science but without focused questioning, they rarely mentioned their own activities or lives as examples of scientific work (Basu \& Barton, 2007).

González and Moll (2002) introduce 'funds of knowledge' to identify the connection between the students' home experiences and the experiential knowledge of students which can be valued as part of the epistemological tradition of the classroom. They note that funds of knowledge is based on a simple premise that people are competent and have knowledge, and their life experiences have given them that knowledge.
There are the inherent cultural sources found in communities surrounding schools. Funds of knowledge are grounded in the networking that communities do in order to make the best use of those sources. Funds of knowledge are also situated from one household to another or even to a greater community. Funds of knowledge therefore include knowledge, action, and disposition or habits with recognition of how each of these domains are culturally constructed and refined (Basu \& Barton, 2007). There are the connections and interactions from these funds of knowledge.

Incorporating funds of knowledge into learning environments captures the idea that education should promote social relations between schools and homes, which in turn "establish and maintain necessary trust among participants [keeping] the system active and useful" (Bouillion \& Gomez, 2001, p.894). These connections, established between the school and home through a "funds of knowledge lens", are strategic for the teachers to incorporate not only what kinds of knowledge are used at home but also how that knowledge is intentionally used toward a set of greater goals or purposes (González \& Moll, 2002).

The challenge for the teacher is to engage students, from the very beginning of the entire learning process with their funds of knowledge so that they could feel their ideas and experiences are honored so that they believe they have a chance and hand in their own learning. When students bring their culture into the classroom, the teacher should accommodate these students' life experiences for effective teaching and promote "connected science" (Bouillion \& Gomez, 2001) where scientific knowledge is applied to students' real-life situations. This existing situations lead to a comprehensive exploration of the influence aspect of student learning. Fraser-Abder et al. (2006) have identified the need of future research to closely examine the interrelatedness of factors such as race/ethnicity, culture, language, social class, and gender with the culture of the home and street, and science learning and achievement. Furthermore in re-establishing the study of 
Moll, Fraser-Abder et al. (2006) suggest that a challenge for future research is to examine the science-related funds of knowledge existing in different contexts and communities. However, Fraser-Abder identified that the literature connecting the cultures of the home to the science classroom is still in limited number.

\section{METHOD}

This study is a qualitative method and aimed to examine the teaching of science which incorporates students' funds of knowledge on students' attitudes and interests towards learning science. This study took place in two suburban Junior High Schools in Indonesia. Two science teachers, Mr. Greg and Ms. Martha (all the names are pseudonym), and 173 students which consisted of 94 males and 79 females participated in this study. Their socio-cultural background is varies. In this study, $79 \%$ of students are Javanese, $17 \%$ are Chinese and the rest come from ethnic of Batak, Papua, Melayu, Betawi and Flores.

Prior to design instruction for the teachers, the teachers were trained to incorporate students' funds of knowledge by attending a workshop provided by the researcher. In the workshop, the teachers were trained to incurporate students' funds of knowledge into their teaching. The teachers later used this knowledge and skill to teach in their schools. The aim of this workshop was to enable teachers to incorporate students' funds of knowledge into learning science. In this workshop the problem of learning science which tend to make science foreign to students were discussed. In order to give a clear understanding to teachers regarding the concepts of funds of knowledge, discussion session was established during the workshop.

Classroom observations and interviews related to the teaching preparation and implementation were done with teachers. To facilitate the data analysis, all qualitative data collected were organized carefully. This process involved "tidying up"e data, organizing them into files, labeling the files, transferring them into an electronic format, putting them into directories, and organizing and reducing data according to ideas, themes, units, patterns, and structures that are visible within them. This involves some forms of coding and categorizing data. Teachers' words as included in the following section are edited and translated as all participants use colloquial language (the Indonesian language).

\section{FINDINGS AND DISCUSSION} Findings

\section{Mr. Greg's Preparation for Teaching Practice}

In incorporating students' funds of knowledge, Mr. Greg identified the students' cultures, artifacts, and students' experiences related to physics that can be incorporated into teaching. Mr. Greg put the students' learning experiences in their primary education as an important aspect of their funds of knowledge. Mr. Greg used some artifacts available either around his school or in his students' home to develop the learning material. He preferred to use these materials in providing learning materials for the students rather than directly using apparatus available in the school laboratory. For example, he planned to utilize materials that are familiar to students in designing their own pendulum. He demonstrated a new way of designing instruction that was rarely used before. He used the students' funds of knowledge to generate new and better way of teaching science concepts and explain science concepts that he wants his students to know and to demonstrate the science concepts. Mr. Greg believes that giving students opportunities to develop and arrange the equipment from the materials they are familiar with will be of benefit to them. It also develops a better learning environment for them in terms of their understanding of physics concepts. Mr. Greg saw that physics could be interesting when it offered students opportuneties to engage in practical work, when it offered challenge and stimulation whilst not becoming too difficult or complex, and when it stimulated a sense of wonder. He posed a problem to his students and facilitated them in designing learning materials. He evaluated students' ideas and brought them to find a better solution.

Clearly, the teacher's positive experiences in the social classroom settings motivated 
him to be a culturally and socially sensitive physics teacher. Classroom observation in the early stage of this study shows that most of his students are expected to be told by the teacher on what to do, rather than to decide for themselves. Students were likely to value rote memorization in education and to be unfamiliar with the inquiry processes required in science. However, Mr. Greg believed that inquiry activities need to be integrated in the learning of science in order to find science concepts, and give students an opportunity and freedom to do their own exploration.

To find scientific concept it must be practiced with right order, although I did not stress on this order, the activities actually have been arranged to follow the order, how s/he designs, collects data, records data, formulates question, doing experiment. This entire step actually happens automatically, although I have never, not specifically, but has become habit in the process of teaching (Teacher Interview_1, line 86-91).

I gave them freedom. This mean,... if there are questions, for example, I only give outline..... there is wave ... meaning that they ... eee ... will look for relevant equipment by themselves. I did more like this way. Later on if there are questions which they ask "How and why is this, sir?" then I give a clue to find the answer, but not provide them the whole answer. I prefer students to find the answer for themselves (Teacher Interview_1, line 108-113).

\section{Ms. Martha's Preparation for Teaching Prac- tice}

Ms. Martha had a different way to identify students' culture relevant to physics. She used students' experiences in everyday life and activities to develop her instructional design. Observing student activities was a major concern for Ms. Martha in identifying her students' funds of knowledge. More often she directly invited students to tell her their experiences for an entire day. Through this way she expected to know and understand the culture of her students. The following excerpt illustrated her expectation.
I observe them in one semester then I recognize them by inviting them to share their daily activities, what they do in out-of school, how is his/her family. From the finding, I could recognize them so that I can make conclusions how their culture influence them (Teacher Interview_2, line 8-13).

As well as Mr. Greg, Ms. Martha was aware that the congruence perceived that what was learned by students at school should be useful at home and vice versa. She demonstrated higher levels of congruence between what is taught at school and its usefulness at home to motivate the students. As a new teacher, she tried to figure out the curriculum in order to identify concepts should be delivered to students. She deeply explored the concepts and incorporated students' experiences she found while designing the lesson plan. She stressed on the important of students' daily experience in developing learning activities.

After observation which I did in one semester, I look at the curriculum, then I started to design a learning activity which close and relevant to student, related to everyday life of student, moreover most students come from rural area so that the designed learning activities were not only close to them and relate to environment but also related to their daily life experiences. The first step is to put a design learning activities into instructional design. Then, I explored the concept deeply, so that I could deliver the lesson to student, which will be easy to be understood by students, through using language appropriately and relating the activity with their everyday life. The next step is to arrange classroom so it will be appropriate for students' activities, and then to prepare the supporting facilities (Teacher Interview_2, line 50-58).

\section{Mr. Greg's Science Class}

Before teaching the topic of wave phenomena, Mr. Greg assigned a task to his students to design a simulation of wave using a vibrator. Mr. Greg began the lesson by allowing his students to set-up the materials they had prepared for the simulation. The students then conducted the simulation and when this was completed, 
Mr. Greg led the students in answering the questions in their worksheet. The students were expected to work together in small groups on the experiment. Such group inquiry activities are a typical component of science lessons in Mr. Greg's lessons.

Mr. Greg's students appeared to be accustomed to working in groups and did not appear to require direct or explicit instructions on how to work with each other. Once they began the experiment, they worked together to complete the tasks. Students did not leave their tables or appear to be doing anything other than the activity.

In learning about sound wave, Mr. Greg brought a guitar into the class. This artifact was very familiar to the students. He gave his students some information regarding his guitar. He began by posing some problem to his students. He covered the hole of the guitar with the book and asked his students to predict what will happen if he played the guitar in this condition. He discussed the students' prediction. Then he demonstrated what actually happened when he played the guitar with the hole covered. Using the guitar he also invited his students to learn about frequency, the influence of string type to the frequency of sound, and tone. Finally he introduced the concept of resonance.

The following activity was students' discussion. Students should explain the phenomena they had found during the discussion. All groups wrote their list of the resonance phenomena on the board. Mr. Greg invited a member from each group to explain their findings to other students. He also invited the students from the other groups to ask questions or comment on the results. He questioned each group that was reporting their results. For example, one group reported that the example of resonance in everyday life is the engine. Then Mr. Greg asked this group to describe the phenomenon, which object was vibrating and which object was also vibrating because of resonance. This group successfully explained the phenomena. Using this method, responses from others students occurred. At the end of the lesson, Mr.
Greg made a conclusion to highlight the essential concept of resonance.

In the next lesson, Mr. Greg expected his student to clearly understand the concept of resonance. He bought materials and made four pendulums on a piece of string. Two of the pendulums have similar length. He showed that if he swings the pendulum, the other pendulum that has similar length would also swing with exactly the same frequency. This simulation enabled the students to be clear about the concept of resonance.

\section{Ms. Martha's Science Class}

In Ms. Martha's classroom, she relied more on classroom management at the first stage of implementation to establish classroom environment so that students can work with each other in-group. At the beginning, students require direct or explicit instructions from teacher about how to work with each other.

When she taught the concept of movement of an object, she utilized her students' everyday experiences. She called upon one male student to tell the way he went to school from his house. Ms. Martha asked him to draw up the map on the board and to identify the road he passed by while going to school. Through this map, Ms. Martha discussed with her students about the concept of distance and how to measure it. Ms. Martha also asked him the time required to travel from his house to the school. With this information, she discussed about the concept of speed. On the student's map, the road he used was not a straight road. He should turn left and right. This rich map also provided Ms. Martha evidence to discuss with students the differences between distance and displacement of moving object. The students' understanding of distance and displacement concepts of moving object were important to differentiate the concepts of speed and velocity.

To begin discussing the concept of velocity, in the following lesson Ms. Martha utilized a group discussion. She asked the students to describe "what is velocity?" The students worked in-group and reported orally in front of the class. Ms. Martha typed the report in her com- 
puter and showed it to her students using the projector. She brought a computer in order to show the phenomena of moving object so that students had a good understanding of the concepts. After discussing students' responses or ideas, she highlighted the essential aspect of velocity which included the equation and measurement unit.

After completing the lesson, Ms. Martha assigned a task for the students. The students should work in-group. They were required to do an experiment to measure the velocity or water flow in the river or in the ditch near their house. They need to collect the data and prepare a written report. The following week, the students submitted their report and some members of the groups presented their results. Ms. Martha used this opportunity to develop the students understanding of velocity and to relate science with the students' everyday life.

During the next lesson, Ms. Martha discussed the concepts of acceleration. From the students' interview, there was evidence that most of the students were familiar with riding a bicycle. The students usually used their bicycles after school. They went to their friends' house or elsewhere together. Ms. Martha utilized this experience in developing discussion of aceleration. She did a pseudo-experiment. It meant that one or two students should imagine what they did if they ride a bicycle. Two students pretended they had a bicycle race. Riding their bicycle from idle, and then they increased speed. When they were going to stop at a certain place, they needed to slow down and finally completely stop. In this situation of riding their bicycles, Ms. Martha began to identify the change of velocity. This will be important for the students in their understanding of the concept of aceleration. Finally, she summarized the lessons and highlighted the concept that acceleration made objects move faster or slower than before. The following lesson, she continued to discuss velocity and acceleration in a quantitative way. The method to use the equations and the measurement unit of acceleration was also included.

\section{Identifying Teaching Practices Using Everyday Experiences and Artefacts in Teaching Science}

Ms. Martha was observed talking about students' experiences and using them as examples of different science concepts. Sometimes she used a student's live experience in a science class to demonstrate certain science concepts as well as to provide students with a tool to facilitate their understanding of the concepts, which were related to their everyday life. Ms. Martha introduced the force acts on the by using students' experience in riding a bicycle. Observing her students who enjoyed playing with water in a ditch, she used their experience to conduct an investigation in measuring the speed of water flow. During the interview, Ms. Martha related what her students commented regarding her teaching.

I took examples that related to the physics concept from their experiences in daily life, so that they could easily imagine and think. I received comments from students such as "Oh, this was apparently referred to what you [teacher] were thinking about [physics concept]," "Oh, it appears that there was a relation between my experience and physics." "Oh, I knew that physics is close to our lives." "Oh, when I understand physics, I can use to answer questions and solve physics problems (Teacher Interview_2, line 195201)

Similarly, Mr. Greg used the experiences in everyday life as examples to explain the science concept. To explore the concept of frequency, he encouraged his students to design a simple pendulum using objects they had. In the topics of resonance, he brought a guitar, which most of students had experiences playing with; in order to make the concept as close to the students' experiences in their everyday life as possible. He also stimulated the students to think about the advantages and disadvantages of the resonance phenomena in society.

Very effectively, both teachers were able to connect the students' experiences with science. They utilized their students' experiences to make their science teaching a "connected 
science", where scientific knowledge is applied to the students' real-life situations and students feel more accepted and willing to participate in science learning. The way in which teachers used students' hobbies and favorite activities as well as what they excel at outside the school could systematically tie the students' interests, concerns, and strengths into their teaching, thereby enhance their motivation to learn. Teachers used pertinent examples and analogies from the students' lives to introduce or clarify new concepts. By embedding learning in a meaningful activity on a topic of interest to the students, the teacher provided them with a strong motive to learn.

\section{Supporting Student's Engagement}

Science learning requires the active participation and working together of students. Mr. Greg and Ms. Martha maintained the students' engagement. Ms. Martha maintained the students' engagement mostly by positively evaluating their contributions. Ms. Martha used positive evaluations. For example she encouraged students to talk in front of her class by saying "if you couldn't talk to friend you couldn't learn from each other". She appreciated the students' talk by saying "Thank you”. Mr. Greg also often used this gesture to maintain the students' engagement. Positive and negative responses, which conveyed judgment less directly, were also widely used. One of the most common evaluations observed in both teachers' lesson was statement repetition. Both teachers repeated what a student said, sometimes when it was correct and sometimes when it was incorrect. In this way, the teachers made students feel that their contributions were heard and valued, even when they were not accurate in terms of science knowledge. Negative evaluations such as "No" or "That's not right" were nearly nonexistent.

Ms. Martha tried to initiate students into the social participation structure of learning science as she conveyed the academic science knowledge that students were to learn. Ms. Martha frequently used language to describe students' behavior and to give explicit direc- tions for what students were to do. For example when one of her students was reporting the results of a group discussion but the class was noisy, she will said "Ok... wait till your friends are ready to listen to you" Ms. Martha's extensive use of explicit social structuring had made clear to the students that she expected them to take an active role properly.

By making expectations explicit, Ms. Martha strengthened the boundaries around the classroom community and created a framework in which solidarity could grow. In order to make this environment exist, Ms. Marta made some agreements with her students. For example, always raise a hand when asking questions, try to listen and appreciate friends' speech, and avoid chatting with any friend during the lesson. What is perhaps pleasantly surprising is that the students did not show signs of alienation or resistance and their attention and body movements were seemingly responsive to her reinforcement of expectations.

Ms. Martha often tried to make her students feel that their questions, ideas, experiences, and knowledge were an integral part of science learning. Ms. Martha maintained an attitude conducive to her students' participations. Her students were frequently involved in co-constructing their understanding of the activity with each other. She gave the students opportunities to share their ideas in front of the class. Sometime students felt that they should have the correct answer and not in terms of sharing his opinion. Ms. Martha was fully aware of what was her student's feeling, then made students feel free to share ideas in order to answer her question in class. Ms. Martha wanted her students to learn as many ways to understand science concepts as possible, even starting from inappropriate initial ideas held by her students, by utilizing their experiences and knowledge as important funds of science knowledge. She promoted discussions about topics that, although relevant to the lives of the students, were regularly excluded from classroom conversations.

In Mr. Greg class, he pushed his students to take their own initiative in learning. For 
example, he encouraged his students to design and conduct the experiments by themselves. $\mathrm{He}$ encouraged students to learn via in-group. Even though his students did their activity in-group, he encouraged each student with the experience to make a report individually. Mr. Greg's students were more confident in talking in front of their class or asking questions. He acted as facilitator in his students learning. He used gestures to manage his students' behavior in social participation. For example, when he found a group was noisy during experiment, he went to this group in order to expect his students to pay more attention and did what they should do. However, he effectively did the activities with his student. He moved from one group to another group to maintain engagement.

\section{Guiding Students Learning}

The central task of teachers was to create a classroom environment in which all students are encouraged to make sense of new ideasthat is, to construct knowledge that helps them to better understand the world-rather than merely to memorize facts and information. In guiding students learning, Ms. Martha used scaffolding. She scaffolded by involving students' participation. For example, she threw a question at her students who disengaged in activities in order to get them involved. Ms. Martha also used scaffolding when she controlled the process. She used this scaffolding to clarify or to minimize potential breakdowns. For example, she needed to focus on a student's attention on elements of the message that she had not understood, or in assisting the student in retrieving the correct word. She wanted to facilitate students' success. She established a collaborative dialogue between her and her students, and among students themselves to build knowledge jointly.

Mr. Greg made scaffolding; that was, simply giving the students information. His use of scaffolding was particularly obvious when he reviewed his explanation or questions with the students by giving additional information or examples. Rather than providing scaffolds to assist students in thinking about the answers, he simply stated his preferred answers. For example, when he demonstrated playing guitar, he asked students to predict what would happen if the hole of guitar was covered. Even though there were many students' responses, he waited for the expected answer before he provided them with his response, stating, "The sound of guitar will fade when being covered than before being covered"

\section{Discussion}

Incorporating students' funds of knowledge into the teaching of science put students' culture as the important and valued aspects considered in students learning. It was also identified that the Indonesian Ministry of Education and Culture (Depdiknas, 2006) have highlighted the importance of the learning environment by stating that along with the teacher, teaching methods, curriculum and resources, the learning environment (natural, social, and cultural) determines the teaching and learning processes and thus in turn influences the students' outcomes. This document emphasizes the role of cultural dimensions of the learning environment in improving classroom teaching and learning.

Several researches had incorporated students' fund of knowledge into science classrooms, and this had revealed several strategies for achieving this goal such as; utilized students live (Upadhyay, 2006), incorporated students' voice (Furman and Barton, 2006), focus on real-world problems (Bouillion and Gomez, 2001), and project-based science (Schneider, Krajcik, Marx, and Soloway, 2002). Through out these strategies the science instruction will be more congruence. Lee and Fradd (2001) summarize the four important features of instructional congruence, teachers need to; integrate knowledge of cultures with the nature of science; consider the nature of science content and scientific inquiry; promotes student learning; and put constructivism is a core aspect in students learning.

In this study, both teachers utilized their students' experiences, familiar activities, and artifacts as funds of knowledge into learning 
science through a variety of activities. The finding shows that incorporating students' funds of knowledge successfully into a science classroom was very challenging for teachers. This new method is quite different from their previous teaching habit. This situation was similar to Seiler (2001) who summarized that the struggles in a "We were battling our own and others' perceptions that science is a collection of facts laid out in a book and not a collection of topics connected to everyday lived experiences" (Seiler, 2001).

The teachers considered the learning effects of the use of everyday contexts in physics/science teaching; they recognized the differences of the methods of knowledge construction in everyday and scientific domains. The developed instructions which incorporate students' experiences, familiar activities, and artifact as funds of knowledge in learning allow teachers the opportunities to experience the process that requires "border crossing" (Aikenhead, 1997, 2006). As suggested by Costa (1995), the learner's relative match of three domains - the everyday, school, and physics/ science domains need to be considered.

It should be noted here that the students' funds of knowledge had been implemented via different strategies chosen independently by both teachers based on their understanding of their students and the kinds of students' funds of knowledge which should be incorporated into learning. Both teachers believed that incurporating students' funds of knowledge help them to bring science relevant to students and made science related to the students' life so that students could learn science in meaningful way. Reflecting their teaching, the two teachers shared their experiences.

Yes, the obvious benefits is the understanding of physics concepts become closer to them [students], it became something that was not foreign to the concept because of the materials they use are familiar (Teacher Interview_1, line 221-223).

In fact, they are happy with the lessons; their interests grow up. ... Moreover, after leaving the class they always ask, "Ms., what else we learn at tomorrow?" It made me challenging. It was most likely they felt interested in the learning process that has already done (Teacher Interview_2, line 204-209).

These are consistent with González and Moll (2002) findings that teachers who are able to bridge students' funds of knowledge with classroom instructions provide the most meaningful learning experiences to their students. Teacher's decisions are important because during teaching, students bring many experiences, ideas, questions, and knowledge from beyond the classroom; teachers have to include these experiences in ways that help students understand, participate, and experience science in a meaningful ways (Barton \& Yang, 2000).

Integrating knowledge of students' cultures with science concepts in the congruent instruction perceived that what is learned at school is useful at home and vice versa. In this study, teachers showed an effort to demonstrate congruence between what was taught at school and its usefulness at home to motivate some low-achieving students. Despite establishing and maintaining instructional congruence and the teacher's attempts to mediate the nature of academic disciplines with students' cultural experiences to make science accessible, meaningful and relevant; yet the students were not fully focused to explicitly consider and master new ways of thinking (scientific thinking).

The activity encouraged students to relate science to immediate real-life situations that they had encountered. Consistent with Aikenhead's (2001), González and Moll's (2002) findings, and also with Roth and Lee's (2004) finding, students were able to contribute to their science learning because their teacher allowed them to engage in science that had personal relevance to students. Here, the teacher was using students' knowledge accumulated through lived experiences as funds of knowledge to generate new and better science concepts as well as to teach and explain science concepts that the teacher wants her students to know. Teachers often utilized students' experiences to make science teaching more relevant to students and 
science was connected to the experiences (Bouillion \& Gomez, 2001), where scientific knowledge was applied to students' real-life situations and students feel more accepted and willing to participate in science learning. Some students commented, in science class they could talk about what they knew and they felt very encouraged and enthused about sharing their knowledge from their home experiences. Here, the teacher's teaching has clearly encouraged, excited, and involved students in science learning, who otherwise might not have actively participated in science conversations.

In considering the nature of science content and scientific inquiry, both teachers had delivered activities such as demonstration, experiment, and group work and/or discussion during implementation. These provided students with the opportunities to interact and communicate each other. During such interactions, the students had the chance to gain resources for further conversations. In this manner, the teachers established interactions that provide resources for building community and the establishment of student engagement both emotionally and cognitively.

In order to develop an understanding of scientific inquiry, students collaboratively engaged in activities. However, it had been observed that both teachers need to put more emphasis on developing inquiry skills rather than only presenting activities in more interesting ways. This was in line with Subali and Mariyam's (2013) finding that based on students' perspective, teacher rarely focus on developing science process skills in the lesson.

In any science class, the teacher still need to focus more on students' development, for example, in asking and refining questions, designing and conducting investigations, gathering and analyzing data, making interpretations, drawing conclusions, and reporting findings in a social context. This is particularly so because the teaching of science should be congruent with scientific inquiry, and include the development of students' understanding of inquiry and the nature of science (Bybee, 2003). Through this effort, students will not only develop an understanding of scientific inquiry and concepts, but also acquire the scientific inquiry process skills necessary to engage in further scientific exploration.

This study also indicated that science activities involving the use of familiar materials and utilizing students' everyday lives are resources offering opportunities for students and teachers to co-explore physical phenomena and interactions that can support the emergence of positive emotional involvement. Good support established by teacher and friends was an example of good attitudes intentions as a tool for developing a process of students crossing emotional and cultural borders and furthermore for a process of a reflective teacher as a cultural broker.

The students learnt science talk when they participated in doing science activities, which involve talking science. In this situation, students used language as a vehicle to share their thought. The teachers often used questions to provoke the students' thinking. The teachers' frequent use of questions demonstrated that they placed a premium on knowing science and using correct terminology. Consideration of the students' language background gave insight into the challenges faced in acquiring the concepts and vocabulary they needed to know in science. Both teachers modeled the use of correct scientific terms, led the students to use these terms in their responses, and praised their students for using the right words.

The students seemed to become more confident in communicating their ideas/ thoughts to the others when their respective teachers set up a supporting classroom environment. The teachers often stressed that what their students were talking about was important in learning. Through this way, students felt that the learning of science became more exciting when they shared knowledge. The excitement that they communicate what they now know resulted from broader activities within a supportive learning environment. Here, the words change with context. The meaning students were developing was the result of a perspective that students look at with their teachers, on 
science concept being developed/explored, as they try to communicate successfully.

What I did was to invite student to speak in front of the class, after his/her speech was finished, I asked questions related to his/her experiences then I invited her/him to articulate what his/her thinking in a scientific way. I guided them to formulate, write to the language that was more scientific (Teacher Interview_2, line 477-482).

This validates that from the socio-cultural perspective (Vygotsky) that everyday (or spontaneous) experience/ideas become more scientific (or academic) over time when given assistance by a teacher. Teachers helped students to develop a scientific discourse from students' everyday discourses (Moje et al., 2001). In addition to knowing scientific vocabulary and concepts and being able to engage in the scientific inquiry process, students learnt to develop their talking in scientifically literate ways; they gradually know the academic genre styles. This is in line with Vygotsky's (1978) suggestion that signs, utilizing language and other cultural symbols; mediate all human activity, as language is the medium for learning and teaching.

As constructivism is a core aspect in instructional congruence, the teachers demonstrated the use of scaffolding in terms of controlling the process, clarifying or in minimizing potential breakdowns, cuing and clarification or even in simply giving the students information during students learning. Nevertheless, scaffolds to assist students in thinking were rarely implemented. Through scaffolding, teachers let students do the talking in a science class. The existence of students talk revealed that sharing authority emerged in the classroom. In constructivism, teachers share some authority with students in the classroom through a restructuring of interaction, the establishment of explicit opportunities for student participation, and increased flexibility with time (Patchen \& Cox-Petersen, 2008). The teachers supported student participation and a valuing of student thinking necessary to rebalance authority and encourage student interaction were evident in the use of questions in classrooms. However, teachers infrequently extended students' contributions in any substantive way beyond merely repeating what they said.

However, the fundamentals of constructivism emerged in classrooms in this study: a belief in the power of participation, the recognition of the value of student perspectives, and a desire to hear from students manifested in the support of oral participation through questioning. Such opportunities for oral participation are critical not only in social constructivism (Vygotsky, 1978) but also in the establishment of relationships and understandings necessary to support the teacher's role in implementing instructional congruence.

The support for oral participation can result in a redistribution of authority between students and their teachers, as students increasingly move from participating in discussions to leading them. Thus, even in a limited capacity, encouraging participation did bring science instruction one step closer to connecting the borders between students' ideas and cultures, increasing the relevance of science instruction to their lives (Costa, 1995; Jegede \& Aikenhead, 1999).

\section{CONCLUSION}

In summary, both teachers used their students' funds of knowledge that were accumulated and culturally developed to engage in learning science. Teachers are valuable resources for the schools involved in this study because they have the ability to identify and connect their teaching with the social and cultural resources of their students (González \& Moll, 2002) and utilize those resources to support their students who embody diversity. Through this study, findings reveals that "compatibility" between students' real-life experiences, their funds of knowledge, and science concepts can be the major factor in sustaining science learning in science classes. It is important worthwhile to develop the teaching and learning of science which put emphasis on incorporating students' funds of knowledge especially in presenting science that is relevant 
to students' everyday life. This includes the important aspects of integrating students' live experience into teaching and learning science.

\section{ACKNOWLEDGEMENT}

I am grateful to my colleagues in the Physics Education Department and Sanata Dharma University who supported this research.

\section{REFERENCES}

Aikenhead, G. S. 1997. "Toward a First Nations Cross-Cultural Science and Technology Curriculum". Science Education 81, 217238.

Aikenhead, G. S. 2001. "Integrating Western and Aboriginal Sciences: Cross-Cultural Science Teaching”. Research in Science Education, 31, 337-355.

Aikenhead, G. S. 2006. Science Education for Everyday Life: Evidence-Based Practice. New York: Teacher College.

Barton, A. C., \& Yang, K. 2000. "The Culture of Power and Science Education: Learning from Miguel". Journal of Research in Science Teaching, 37(8), 871-889.

Basu, S. J., \& Barton, A. C. 2007. "Developing a Sustained Interest in Science among Urban Minority Youth". Journal of Research in Science Teaching, 44, 466-489.

Bouillion, L. M., \& Gomez, L. M. 2001. "Connecting School and Community with Science Learning: Real World Problems and School-Community Partnerships as Contextual Scaffolds". Journal of Research in Science Teaching, 38(8), 878898.

Bybee, R. W. 2003. "The Teaching of Science: Content, Coherence, and Congruence". Journal of Science Education and Technology, 12(4), 343-358.
Costa, V. B. 1995. "When Science is "Another World": Relationships between Worlds of Family, Friends, School, and Science". Science Education, 79, 313-333.

Depdiknas. 2006. Standar Kompetensi Lulusan untuk Satuan Pendidikan Dasar dan Menengah. Jakarta: Departemen Pendidikan Nasional.

Fraser-Abder, P., Atwater, M., \& Lee, O. 2006. "Research in Urban Science Education: An Essential Journey". Journal of Research in Science Teaching, 43(7), 599606.

Furman, M., \& Barton, A. C. 2006. "Capturing Urban Student Voices in the Creation of a Science Mini-Documentary". Journal of Research in Science Teaching, 43(7), 667-694.

George, J. 1999. World View Analysis of Knowledge in a Rural Village: Implications for Science Education. Science Education, 83, 77-95.

González, N., \& Moll, L. C. 2002. "Cruzando el Puente: Building Bridges to Funds of Knowledge". Educational Policy, 16, 623-641.

Jegede, O. J., \& Aikenhead, G. S. 1999. "Transcending Cultural Borders: Implications for Science Teaching". Journal for Science \& Technology Education, 17(1), 45-66.

Lee, O., \& Fradd, S. H. 1998. "Science for all, Including Students from non-EnglishLanguage Backgrounds". Educational Researcher, 27(4), 12-21.

Lee, O., \& Fradd, S. H. 2001. "Instructional Congruence to Promote Science Learning and Literacy Development for Linguistically Diverse Students". In D. R. Lavoie \& W. M. Roth (Eds.), Models of 
Science Teacher Preparation (pp. 109126). Netherlands: Kluwer.

Lim, M., \& Barton, A. C. 2006. "Science Learning and a Sense of Place in an Urban Middle School". Cultural Studies of Science Education 1, 107-142.

Moje, E., Collazo, T., Carrillo, R., \& Marx, R. 2001. "Maestro, "What is Quality?" Language, Literacy, and Discourse in Project-Based Science". Journal of Research in Science Teaching, 38(4), 469-498.

Patchen, T., \& Cox-Petersen, A. 2008. "Constructing Cultural Relevance in Science: A Case Study of Two Elementary Teachers". Science Education, 92, 994 1014.

Roth, W. M., \& Lee, S. 2004. "Science Education as/for Participation in the Community". Science Education, 88(2), 263291.

Schneider, R., Krajcik, J., Marx, R., \& Soloway, E. 2002. "Performance of Students in Project-Based Science Classrooms on a National Measure of Achievement". Journal of Research in Science Teaching, 39, 410-422.

Seiler, G. 2001. "Reversing the "Standard" Direction: Science Emerging from the Lives of African-American Students". Journal of Research in Science Teaching, $38,1000-1014$.
Semiawan, C., \& Natawidjaja, R. 2000. The Dynamics of an Education System of a Developing Country: The Case of Indonesia. In K. Mazurex, M. A. Winzer \& C. Majorek (Eds.), Education in a Global Scciety: a Comparative Perspective (pp. 399-408). Needham Height, M.A: Allyn \& Bacon

Subali, Bambang \& Mariyam, Siti,. 2013. "Pengembangan Kreativitas Keterampilan Proses Sains dalam Aspek Kehidupan Organisme pada Mata Pelajaran IPA SD". Cakrawala Pendidikan, XXXII (3). 365-381.

Upadhyay, B. R. 2006. "Using Students' Lived Experiences in an Urban Science Classroom: An Elementary School Teacher's Thinking". Science Education 90, 94 110.

Vygotsky, L. S. 1978. Mind in Society: The Development of Higher Psychological Processes. Cambridge MA: Harvard University Press. 